\title{
Enhancement of Carbon Sequestration in Soils under Climate Change Scenario in India
}

\author{
G.N. Gurjar* and Sanjay Swami \\ School of Natural Resource Management, CPGSAS, Central Agricultural University, \\ Umiam, Meghalaya, India-793103 \\ *Corresponding author
}

\begin{abstract}
A B S T R A C T
Keywords

Carbon sequestration, Crop residue, Cover crop

Article Info

Accepted:

07 January 2019

Available Online:

10 February 2019

Carbon sequestration is the most important and necessary for good crop production under climate change from the agricultural soils. The increase in gaseous concentration of carbon dioxide, methane and various other gases results decreased crop production, change in soil chemical and biological properties like soil texture, soil structure, soil organic matter content and elemental concentration as well as change in bacterial and fungal populations. The soil organic residue which upon decomposition cause release of various forms of carbon as gases causes lower carbon content of soils and also the repeated and intensive cultivation. So, it is necessary to conserve soil carbon by using various crop production techniques to conserve natural resource by adding carbon to agricultural soils. In this paper we are discussed some important modern techniques to add carbon to soils technically known as carbon sequestration such as crop cover, crop residue management, crop rotations etc.
\end{abstract}

\section{Introduction}

Climate change is not only the national issue but it becomes a global issue to conserve natural resources to maintain production and productivity of the soils without destroying our natural environment to sustain human life on the planet earth. Now a days, the climate is totally different from the ancient times due to overuse of natural resources to supply food for increasing human population, which leads to increase in various gaseous concentration in our environment such carbon-dioxide, methane, nitrous oxide and chlorofluorocarbon. Agricultural soils are capable of being a source or sink for atmospheric carbon dioxide depending upon the supervision practices and land use systems. Progressive enlarge in the concentration of green house gas (GHGs) since industrial era has created worldwide attention in identifying strategies to lessen concentration of these gases in the environment. Climate change has emerged a most important face up to not only for sustainable agriculture but also for human arrangement. Effect on climate change including global warming with its unhelpful impact on the living things on the earth is now global issue and appropriate strict day by day. Increase in the carbon dioxide concentration with the results of global warming in the 
atmosphere which is directly or indirectly related to climate change. The human activities that change the composition of global atmosphere adversely impact. In the systematic models and observations over the past one thousand years provide evidences that global warming may due to anthropogenic enhance in (GHG's) including that of carbon dioxide, methane, carbon monoxide. The increased atmospheric concentration of $\mathrm{CO}_{2}$ may power soil temperature, distribute erratic pattern of precipitation, evaporation and ensuing changes in the physico-chemical and biological properties in soil. Hence there is need has stress to reduce the concentration of carbon dioxide in the atmosphere and increase the carbon concentration in the soil through the process known as carbon sequestration. Carbon sequestration is an essential technology for the preservation of optimum $\mathrm{CO}_{2}$ level in the atmosphere, which in-turn grades in reducing the recent increase in atmospheric carbon dioxide, contributing to global warming. A substantial part of depleted soil organic carbon pool can be restored from side to side change of marginal lands into restorative land use systems, embracing of conservation tillage with cover crops and crop residue, mulch, nutrient cycling and use of organic manure and other systems for sustainable management of soil and water possessions.

Climate change is flattering a distressing issue today due to increasing amount of greenhouse gases (GHGs) in the atmosphere. It may perhaps be controlled by mitigating GHGs especially carbon dioxide, by sequestering carbon into soil and vegetative cover. The major GHGs are carbon dioxide $\left(\mathrm{CO}_{2}\right)$, methane $\left(\mathrm{CH}_{4}\right)$ and nitrous oxide $\left(\mathrm{N}_{2} \mathrm{O}\right)$. The concentration of $\mathrm{CO}_{2}, \mathrm{CH}_{4}$ and $\mathrm{N}_{2} \mathrm{O}$ in the environment since industrial uprising increased by 30,145 , and $15 \%$, respectively due to human activities (IPCC, 2007).
Climate change will reflect in extreme weather events, spatial and inter-annual variability in weather events, which will negatively affect crop yield.

The $\mathrm{CO}_{2}$ is a sole GHG which traps long length wave radiation reflected from the earth's surface and doubtless the only one that has a major role in plant physiology. Increased stage of $\mathrm{CO}_{2}$ be capable of basis the stomata of the plants to close partially which reduces transpiration. $\mathrm{CO}_{2}$ causes 7.5 percent of the total global warming. Soil, vegetation and the ocean are considered potential sinks of carbon dioxide because of the large quantities of carbon dioxide currently sequestered in these pools and their capacities to continue taking up carbon dioxide. Photosynthesizing vegetation takes up carbon dioxide and sequesters it as biomass carbon in the terrestrial carbon pools of the soils. The restoration of soil quality through carbon sequestration is major concern for tropical soils. The accelerated decomposition of soil organic carbon due to agriculture resulting in loss of carbon to the atmosphere and its contribution to the greenhouse effect is a serious global problem.

\section{Enhancement of carbon sequestration}

Soils are the largest carbon reservoir of the terrestrial carbon cycle. It stores large amount of soil organic carbon (SOC), which is originated from plants and animal tissue that continue living at different stages of decomposition. Improved soil management practices have exposed that systematic agriculture might be due to elucidation to environmental issues in general and specifically for mitigating the greenhouse effect by rising soil carbon storage and successfully removing $\mathrm{CO}_{2}$ from the environment. Soil management techniques like increasing soil organic matter, reduced tillage, manuring, residue incorporation, 
improving soil biodiversity, aggregation, and mulches being play important roles in soil sequestration carbon. There are number of carbon sequestration techniques are available. The most important techniques are discussed here like

1. Conservational tillage technique

2. Crop cover technique

3. Crop rotations technique

4. Crop residue management techniques

5. Nutrient management technique

6. Land use management technique

7. Soil amendment technique

\section{Conservation tillage technique}

Conservation agriculture (CA) is refer as minimal soil disturbance (no-till) and permanent soil cover (mulch) combined with rotations. $\mathrm{CA}$ is dependent three pillars like no- till, mulch and crop rotation. According to Food and Agricultural Organizations (FAO) of the United Nations, conservation agriculture is defined as a concept for resource saving of agricultural crop production that strives to achieve acceptable profits together with high and sustained production levels though concurrently conserving the environment and minimizing or eliminating strategy of the soil for crop production. It was involves an supply of modern agricultural technology to improve crop production, by maximization yields as well as maintain the health and integrity of the ecosystem distinct the traditional systems which mainly goal to maximize yields habitually at the cost of the environment (Dumanski et al., 2006). Conservation tillage involves reducing intensity and frequency of ploughing and leaving crop residues on the soil surface as mulch. This was the important strategy for enhancing SOC content and organic matter. Soil microbial biomass carbon was often found to be higher, but never lower, under zero tillage than under conventional tillage. Yet, $\mathrm{CO}_{2}$ evolution (basal respiration) was generally higher under conventional tillage than under zero tillage, ensuing in higher specific respiration under conventional tillage than under zero tillage. The superior additions but lower losses of labile $\mathrm{C}$ under zero tillage stand for that more $\mathrm{C}$ is sequestered in the soil in the zero-tillage system. CA improves agriculture by decreasing erosion, improving water infiltration, getting better soil surface aggregates, falling compaction through promotion of biological tillage, increasing organic matter, moderating soil temperatures, and suppressing weeds. It also helps in dropping costs of production, saves time, increases yield through timelier planting, decreases diseases and insect pests through encouragement of biological diversity and decrease greenhouse gas emissions (Hobbs, 2007). Thus, this system contributes less to atmospheric $\mathrm{CO}_{2}$ than conventional tillage, and soil organic matter accumulates more under zero tillage.

\section{Cover crops techniques}

Cover crop is utilized of crops such as legumes and small grains for defence and soil development between periods of regular crop production. Cover crops recover carbon sequestration by enhancing soil structure and adding organic matter to the soil. Pulses append a significant quantity of organic carbon to soil since of their ability for atmospheric (Ganeshamurthy, 2009) nitrogen fixation, leaf shedding ability and better below-ground biomass. Venkatesh et al., (2013) reported that the study seven cropping cycles the changes in soil organic carbon pools due to the addition of pulses in an upland maize-based cropping system in Inceptisols of Indo-Gangetic plains. The outcome of the inclusion of pulses improved the total soil organic carbon content. It was more in surface soil $(0-20 \mathrm{~cm})$ and declined 
with increase in soil depth. Maize-wheat mungbean and pigeonpea-wheat systems resulted in significant enlarge of 11 and 10 percent respectively in total soil organic carbon, and 10 and 15 per cent in soil microbial biomass carbon, respectively, as compared with a conventional maize-wheat system. The supply of crop residues along with farmyard manure at $5 \mathrm{Mg}$ ha-1 and biofertilizers resulted in superior amounts of carbon fractions and higher carbon management index than in the in charge of and there commended inorganic fertilizers $(\mathrm{N}$, $\mathrm{P}, \mathrm{K}, \mathrm{S}, \mathrm{Zn}, \mathrm{B})$ treatment, particularly in the system where pulses were incorporated. The effectiveness of conservation tillage in SOC sequestration is enhanced by use of cover crops, such as clover and grains. Frequent use of pod type legumes and grasses in rotation with food crops is an important strategy to enhance SOC and soil quality (Entry et al., 1996). Hence, it may be concluded that cover crops helped to encourage biological soil tillage through their roots. The surface mulch provided food, nutrients and energy for earthworms, arthropods and micro-organisms below ground that also biologically till soils.

\section{Crop rotation technique}

Crop rotation is a progression of crops grown in returning succession on the same area of land. It improves the soil structure and fertility of soil by irregular deep rooted and shallow rooted plants. A crop that leaches one type of nutrient from the soil is followed during the next growing season by a disparate crop that returns that nutrient to the soil or draw diverse ratio of nutrients. Changing the kind of crops grown can increase the level of soil organic matter. However, helpfulness of crop rotation depends on the kind of crops and crop rotation times. The chief component of crop rotation is refill of nitrogen through the use of green manure in series with cereals and other crops. Organic crop rotation include cultivation of deep rooted legumes which increase the carbon content in deeper soil layer by rhizo-deposition and deep root biomass. It also leads to more effective make use of nitrogen and integrated livestock production. Different long term field experiments were conducted to compare crop sequencing with mono-cropping. Continuous maize cultivation with a legume-based rotation was studied by Gregorich et al., (2001). After 35 years, the difference between monoculture maize and the rotation was 20 tonne $\mathrm{C}$ ha-1. In adding together, the SOC present below the ploughed layer in the legume-based rotation appeared to be more biologically resistant, indicating the deep rooted plants were useful for increasing carbon storage at depth. Santos et al., (2011) observed that the basis of research done for 17 years that the forage-based rotations of semi-perennial alfalfa and annual rye grass for hay production contributed more to soil organic $\mathrm{C}$ sequestration than rotations based on cover crops. It was concluded that the roots, either in forage based or cover crop based rotations, played a more relevant role in building up soil $\mathrm{C}$ stocks in no-till Ferralsol than shoot residues. Cropping systems provide an opportunity to produce more biomass $\mathrm{C}$ than in a monoculture system and to thus increase SOC sequestration. Chander et al., (1997) reported that the soil organic matter under different crop rotations for 6 years and found that inclusion of green manure crop of Sesbania aculeate in the rotation improved the soil organic matter status and microbial C increased from $192 \mathrm{mg}$ $\mathrm{kg}-1$ soil in pearl millet wheat fallow rotation to $256 \mathrm{mg} \mathrm{kg}^{-1}$ soil in pearl millet wheat green manure rotation. Legume-based cropping systems might be due to increase crop productivity and soil organic matter levels, thereby enhancing soil quality, as well as having the additional benefit of sequestering atmospheric $\mathrm{C}$. The soil organic matter below the plough layer in soil under the legume 
based rotation appeared to be in more biologically resistant form (i.e., higher aromatic $\mathrm{C}$ content) compared with that under monoculture.

\section{Crop residue management technique}

Management of crop residues is of primary need in the incorporation of soil leads to increased soil organic matter levels. Amalgamation of rice and wheat crop residues helps in sequestering $\mathrm{C}$ in agricultural soils. Amalgamation of crop residues significantly increased soil organic $\mathrm{C}$ content in a long term field experiment conducted in rice-wheat cropping system (Singh et al., 2000). Cereal crop residues with high $\mathrm{C}$ : $\mathrm{N}$ ratio leaves more $\mathrm{C}$ in soil for exchange to soil organic matter. The problem of on-farm burning of crop residues has intensified in recent years due to use of combines for harvesting and high cost of labours in removing the crop residues by conventional methods (NAAS, 2012). Burning disturbs the microbial population in the soil, leads to moisture defeat and increases the $\mathrm{pH}$ of soil due to production of ash, which contains $\mathrm{Ca}, \mathrm{Mg}$ and $\mathrm{K}$ ions. Left crop residue in the field is another practice which will have an important impact on the sequestration of carbon. (Lal, 1997) reported that the annual production of crop residue in the world is approximate to be about $3.4 \times 109$ tonnes because 15 percent of the $\mathrm{C}$ present in the residues can be converted to passive organic carbon fraction, this may lead to $\mathrm{C}$ sequestration of $0.2 \times 1015$ g/year. Crop residue below-ground residues and root turnover represented direct inputs into the soil organization, and as such had the potential to make major contributions to SOM stocks (Sanderman et al., 2010). The use of crop residues as mulches has been established useful as it reduces maximum soil temperature and conserves water. Direct drilling of wheat into rice residue using happy seeder is a good quality agronomic practice for wheat, serving to limit the gradual lessening of soil organic matter and at the same time improving soil health. Happy seeder allows zero-till sowing of wheat with rice residue as surface mulch, at the same time as maintaining yield, reduces tillage costs and time saving, avoids the need for burning (Singh and Sidhu, 2014).

\section{Nutrient management technique}

Nutrient management is using of crop residue and judicious use of fertilizer in the field. On a long-term field experiment increased crop yield and organic matter returned to the soil with judicious fertilizer relevance outcome in superior SOC content and biological motion than under embarrassed conditions (absence of fertilizers). The studies and concluded that fertility management practices can enhance the SOC content at the rate of $50-150 \mathrm{~kg}$ ha-1 yr-1 (Lal et al., 1998). Enhancing the nitrogen doses increases quantity of organic matter in soil and phosphorus fertilizer also has a beneficial impact on soil organic C. Integrated nutrient management through farmyard manure, green manure and crop residues is advantageous in increasing organic matter in soil.

\section{Land use management technique}

The land use pattern of India indicates that cropland dominates and followed by forestland. The land use, land use change and forestry sector (LULUCF) includes emissions and removals from changes mostly in forestland, cropland and pasturelands, which sequesters 177 million tonne of $\mathrm{CO}_{2}$ (NAAS, 2014). This sector plays an important role in modifiable the emission profile from the farming sector and provides avenues for increasing the sink. Degraded soils converting under agriculture and other land uses into forests and perennial land use can enhance the 
SOC pool. The scale and rate of SOC sequestration with afforestation depends on climate, soil type, species and nutrient management. Carbon emissions attributed to changes in land use and land cover, cansignificantly affect management strategies that are intended to enhance carbon sequestration and decrease the atmospheric $\mathrm{CO}_{2}$ concentration (Lal, 2001). Mann (1986) also calculated the $\mathrm{CO}_{2}$ emissions associated with crop production on several additional land brought into production, as well as emissions from the change in land use and finished that for the initial 20 years following conversion, changing from non-cropland (i.e. grassland or forest) to cropland was believed to release $750 \mathrm{~kg} \mathrm{C}$ per ha per year. Therefore, in such cases, agroforestry may be another option of conserving soil and improving the SOC pool.

\section{Soil amendment technique}

Soil amendment is any materials that organic and inorganic to improve the soil fertility and increased in carbon sequestration. Soil amendments are also left over crop residues from processes that have favourable properties when added to soil. Generally used amendments comprise municipal bio-solids, animal manures and litters, wood ash, neutralizing lime products, composted biosolids, soil ash, mulches, composted food scraps and a variety of composted agricultural by-products. By totting up these to soil helps in restoring soil quality by balancing $\mathrm{pH}$, adds organic matter, improves water holding capacity, re-establishes microbial communities, and decreased compaction in soil. Separately from improving soil characteristics, soil amendment application, prevent $\mathrm{CO}_{2}$ and methane emissions that would otherwise occur when industrial by products (i.e. bio-solids and other soil amendments) are feeling like.
In conclusion carbon sequestration is very much related to the soil and its management system. Zero or minimum tillage combined with crop residue maintenance on the soil surface helps in sequester carbon, improves water use efficiency and decrease fossil fuel consumption. The energetic processes that manipulate soil quality are complex, and they activate through time at various locations and situations. Soil organic matter is both source of carbon discharge and a sink for carbon appropriation. Cultivation and tillage could be decrease and alteration the distribution of SOC as an appropriate crop rotation might be due to boost or maintain the quantity and quality of soil organic matter, the improvement of soil physical, chemical and biological properties. The go back of crop residues and the application of manure and fertilizers which might be due to all contribute to an increase in soil nutrients and SOC content because require to be combined into a management system for more improvement. Due to limited availability of oxygen decomposition is slow and incorporation of residue into the soil leads to early disintegration and let loose of $\mathrm{CO}_{2}$ hence it should be avoided. Crop rotation contributes to carbon sequestration since it can increase the rate of build-up of SOC at diverse depths in the soil profile, as various crop species have different root depths. The negative important impacts of monoculture are predisposed by kind of crop with fauna insolvency, a greater than before number of crop pests, a refuse in activities of dehydrogenase and phosphatase, and increased levels in the soil of phenolic acids. SOC was conserved by with crop rotations with reduced tillage rate of recurrence and flourishes of chemical fertilizers, crop residues and manure. There is require for obtaining the more data on long term effects of different tillage systems on carbon and nitrogen mineralization and immobilization in diverse field situations. The matter concerned 
in understanding the soil quality and soil systems for agricultural sustainability have to be more holistic, and it needs further investigation. It helps in improving soil fertility that stimulates plant escalation which ultimately increases the biomass foremost to higher $\mathrm{CO}_{2}$ utilization.

In conclusion, as we knew that the carbon dioxide level of the environment is increasing at a steady state level since the ancient time. But the present situation is going to be very high and in the near future the carbon dioxide level will be reached at a critical level which is very harmful and causing various changes in the environment leads to change in our climate scenario. So, under such environmental condition we have to utilize the higher amount of carbon dioxide available in the natural system through carbon sequestration techniques. In modern agricultural production system huge amount of $\mathrm{CO}_{2}$ is releasing into the environment that only possible to manage by using the crop production techniques to utilize more amount of carbon dioxide and sequester into the soil by incorporation crop residue, crop and land management techniques as well as superior nutrient management for commercial crop production.

\section{References}

Chander, K., Goyal, S., Mundra, M.C. and Kapoor, K.K. (1997). Organic matter, microbial biomass and enzyme activity of soils under different crop rotations in the tropics. Bio Fert. Soils, 24(3): 306310.

Dumanski, J., Peiretti, R., Benites, J.R., Mc Garry, D. and Pieri, C. (2006). The paradigm of conservation agriculture. Proc. World Assoc. Soil Water Conserv., pp. 58-64.

Entry, J.A., Mitchell, C.C. and Backman, C.B. (1996). Influence of management practices on soil organic matter, microbial biomass and cotton yield in Alabama's "old rotation". Bio Fert. Soils, 23(4): 353-358.

Ganeshamurthy, A.N. (2009). Soil changes following long-term cultivation of pulses. J. Agric. Sci., 147: 699706.

Gregorich, E.G., Drury, C.F. and Baldock, J.A. (2001). Changes in soil carbon under long-term maize in monoculture and legume-based rotation. Can. J. Soil Sci., 81: 21-31.

Hobbs, P.R. (2007). Conservation agriculture: what is it and why is it important for future sustainable food production. $J$. Agric. Sci., 145: 127-137.

IPCC. 2007. Intergovernmental Panel on Climate Change 2007, the Fourth Assessment Report.

Lal, R. (1997). Residue management conservation tillage and soil restoration for mitigating greenhouse effect by $\mathrm{CO}_{2}$ - enrichment. Soil Till Res., 43: 81107.

Lal, R. (1999). Soil management and restoration for carbon sequestration to mitigate the accelerated greenhouse effect. Prog. Env. Sci., 1(4): 307-326.

Lal, R. (2001). The potential of soil carbon sequestration in forest ecosystem to mitigate the greenhouse effect. In: Lal R.. Ed.), Soil Carbon Sequestration and the Greenhouse Effect. Soil Science Society of America Special Publication, 57 Madison, WI.

NAAS. (2012). Management of Crop Residues in the Context of Conservation Agriculture. Policy Paper No. 58, National Academy of Agricultural Sciences, New Delhi.pp.12.

NAAS. 2014. Carbon Economy in Indian Agriculture. Policy Paper No. 69, National Academy of Agricultural Sciences, New Delhi: pp.19.

Sanderman, J., Farquharson, R. and Baldock, J. (2010). Soil carbon sequestration 
potential: A review for Australian agriculture. A report prepared for the Department of Climate Change and Energy Efficiency CSIRO National Research Flagships.

Singh, Y. and Sidhu, H.S. (2014). Management of Cereal Crop Residues for Sustainable Rice-Wheat Production System in the Indo-Gangetic Plains of India. Proc. Indian Natn. Sci. Acad., 80: 95-114.

Singh, Y., Singh, B., Meelu, O.P. and Khind, C.S. (2000). Long term effects of organic manuring and crop residues on the productivity and sustainability of rice wheat cropping system of NorthWest India. In: I P Abrol, K F Bronson, J M Duxbury and R K Gupta. Ed.. Long term soil fertility experiments in ricewheat cropping systems, RWC Paper series, 6, New Delhi. pp. 49-162. Venkatesh, M.S., Hazra, K.K., Ghosh, P.K., Praharaj, C.S. and Kumar, N. (2013). Long-term effect of pulses and nutrient management on soil carbon sequestration in Indo-Gangetic plains of India. Can. J. Soil Sci., 93: 127-136.

\section{How to cite this article:}

Gurjar, G.N., and Sanjay Swami. 2019. Enhancement of Carbon Sequestration in Soils under Climate Change Scenario in India. Int.J.Curr.Microbiol.App.Sci. 8(02): 714-721. doi: https://doi.org/10.20546/ijcmas.2019.802.083 